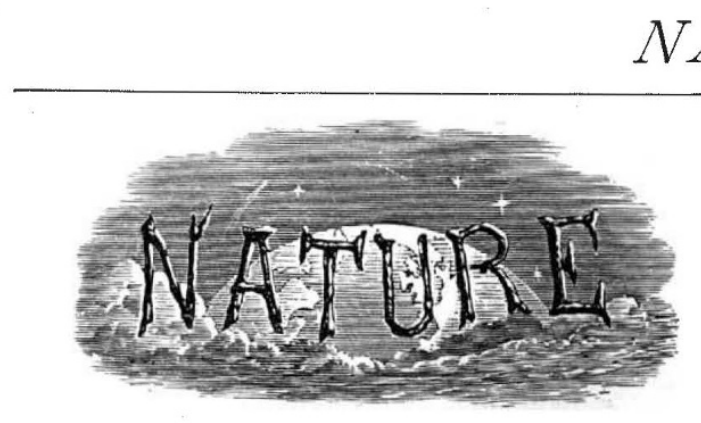

SATURDAY, AUGUST I5, I925.
PAGE

Oil in Navigable Waters

Primitive Law. By

The Metaphysic of Science. By Prof. H. Wildon Carr

An American View of the Agricultural Situation. By E. J. R.

Popular History of Astronomy. By J. L. E. D.

Our Bookshelf

Letters to the Editor :

The Ionisation produced in Air during the complete Absorption of Slow Electrons.-J. F. Lehmann and T. H. Osgood

Lightning-conductors,-Rev, H. C Browne

Fish Poisons as Insecticides.-F. Tattersfield

X-Ray Diffraction Patterns from Plant Fibres.O. L. Sponsler

Doublet Separation in C II and Si IV.-Dr. R. J Lang and Prof. Stanley Smith

The Attraction between Homologous Chromosomes. -Dr. John Belling

Science in South Africa. By General the Right Hon. Jan Christiaan Smuts, P.C. . . .

The Crystalline Structure of Inorganic Salts. By

Prof. W. L. Bragg, F.R.S.

Southampton Meeting of the British Association. Local ArRangemen's, By Dr. W. Rae Sherriffs

Current Topics and Events

Astronomical Column .

Research Items $\quad . \quad$. $\quad . \quad$. $\quad . \quad 257$

The Third International Congress of Entomology. By Dr. R. Stewart MacDougall .

Lathyrism

The Museums Association. AnNual Conference

University and Educational Intelligence .

Societies and Academies

Official Publications Received

Editorial and Publishing Offices:

MACMILLAN \& CO., LTD.

ST. MARTIN'S STREET, LONDON, W.C.2.

Editorial communications should be addressed to the Editor. Advertisements and business letters to the Publishers.

Telephone Number: GERRARD 8830.

Telegraphic Address: PHUSIS, WESTRAND, LONDON.
Oil in Navigable

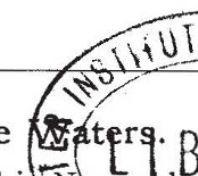

I. a recent publication ("Oil in de avigable Waters," H.M.S.O., $1925,6 d$.) the Bdźr $\$$ of Trade has made a valuable contribution to ticem problem abating the pollution of the sea by oil. The inquiries made by the engineering staff show that those ships which carry fuel oil in bulk and use their oil tanks for water ballast are the most likely to cause pollution at present, and in the near future. In these cases a large bulk of water is mixed with oil, and is separable from the oil only with difficulty and uneconomically. It is considered that separators can now be designed to deal with any ordinary mixture of oil and water so efficiently that the water discharged from this mixture into the sea is sufficiently free from oil to be innocuous, and the provisions of the Oil in Navigable Waters Act of 1922 are ensuring that oil-free water from such mixtures is being pumped into the sea at least within the three-mile limit. Nevertheless, if the shores of Britain are to be kept free from oil, it will be necessary to extend the limit to a much greater distance than three miles to restrict the pollution to that oil, which, Lord Bearsted has pointed out in the Times, may be escaping from vessels sunk during the War.

It is known (see Orton, NATure, vol. 90, I9I3, p. 700) that continuous strong south-westerly winds will blow the Portuguese Man-of-War (Physalia) and Velella from the sub-tropical Atlantic regions up the Channel on to the southern shores of England, over a distance which must be reckoned at least in several half-hundreds of miles; hence there can be no doubt that continuous strong inshore winds may blow oil from deep water on to the shores, notwithstanding tidal currents. It is also apparent that oil discharged in an estuary outside the three-mile limit, but on an incoming tide, may easily result in an accumulation of oil on the shore.

With regard to this aspect of the problem, Mr. A. W. Bibby has recently pointed out that British merchant ships would be at a still greater disadvantage in comparison with foreign ships, if the limit were extended and applicable only to British ships, and that, therefore, we must look to an international agreement to extend the distance within which oil may not be discharged at sea, say, to ten miles off-shore, to give greater protection to the shore. There are signs that the sensitiveness of nations with regard to any alteration of the territorial three-mile limit is breaking down in the recent Anglo-American agreement to permit examination of British vessels inside a ten-mile limit from the American coast. The influential body comprising the American National Coast Anti-Pollution League -which has passed a resolution "that the dumping of oil waste and refuse is ruining the bathing beaches NO. 291 I, VOL. I I 6$]$ 
situated on the territorial waters of the various countries, that the pollution takes place on high seas as well as territorial waters, that the President of the United States was authorised and requested to call a Conference of Maritime Nations with a view to adopting effective means for the prevention of the pollution of navigable waters "- -is also apparently ready to approve an agreement giving greater protection to all shores.

The inquiries made by the Board of Trade brought from local and harbour authorities, coastguards, sea fisheries committees, and district inspectors of fisheries, numerous observations on the deplorable destruction of sea-birds from contact with oil ; cases of damage to paintwork of boats, piers, and other permanent structures ; risk of fire in enclosed waters, and a variety of opinion on the effect of oil on " fish" life. With regard to opinions on the effect of oil on marine organisms, they are mainly uncritical, but the statement by the North-eastern Sea Fisheries Committee that "crabs, lobsters, shrimps, and prawns are quickly smothered and killed by oil," is worth substantiation, as is also that made by more than one body that oil causes fishing-nets to rot very quickly. There is a general agreement in the replies that pollution has decreased markedly in most areas since the introduction of the Oil in Navigable Waters Act, I9z2.

Among the general public there is, fortunately, much interest in problems connected with the loss of oil at sea, and many valuable observations have been made in the Press. Lord Rayleigh has calculated that halfa-million tons of oil could cover the whole ocean with a film, but has not postulated the conditions in which it would do so. Prof. H. E. Armstrong has stated that a film of oil would not deprive marine life of oxygen or light, but might react on that life in an insidious but undefined manner. It has been pointed out that oil bubbles into the Caspian Sea in a perpetual stream, but that although fishing is poor in the locality of the escaping oil, there is heavy fishing in neighbouring parts of that sea, and other writers have observed that oil which has risen to the surface of water in oil-bearing regions, has after a short time sunk again after the evaporation of the lighter constituents. The latter observations are hopeful in considering the fate of floating masses of oil, and are well worth further investigation.

The sum of the information now available on these problems is useful, but might be made still more valuable if followed up by an enumeration and chemical examination of (I) the different kinds of fuel oils, and (2) the waste oils actually discharged from the bilges or tanks of oil-burning vessels. A certain amount of data on these matters exists, but a departmental investigation would collect and place on record together just that kind of information we at present lack.

\section{Primitive Law.}

Primitive Law. By E. Sidney Hartland. Pp. vi +222. (London: Methuen and Co., Ltd., 1924.) 7s.6d.net.

$\triangle$ NTHROPOLOGY is to most laymen and to A. many specialists still mainly an object of antiquarian interest. There are, however, certain aspects of it which are of a genuine scientific character, in that they do not lead us beyond empirical fact into realms. of uncontrollable conjecture, in that they widen our knowledge of human nature, and in that they are of a direct practical application. I mean such a subject, for example, as primitive economics, important for our knowledge of man's economic dispositions and of value to those who wish to develop the resources of tropical countries, employ indigenous labour and trade with the natives. Or again a subject such as the comparative study of the mental processes of savages, a line of research which has already proved fertile to psychology and might be made useful to those engaged in educating or morally improving the native. Last, but not least, there is the subject of primitive law, the study of the various forces which make for order, uniformity and cohesion in a savage tribe. The knowledge of these forces should have formed the foundation of anthropological theories of primitive organisation and it should have yielded the guiding principles of Colonial legislation and administration. Yet of all branches of anthropology, primitive jurisprudence has received in recent times the scantiest and the least satisfactory treatment. This is the reason why the present book by Mr. Sidney Hartland deserves special attention, devoted as it is exclusively to the discussion of primitive law and written by one who is both a learned anthropologist and a professional lawyer.

Anthropology has not always been so indifferent about savage justice and the methods of its administration as it is at present. About half a century ago there was a positive epidemic of research into primitive law, especially on the Continent, more particularly in Germany. It is enough to mention the names of Bachofen, Post, Bernhöft, Kohler and the other writers grouped round the Zeitschrift für vergleichende Rechtswissenschaft, to remind the sociologist of the scope, volume and quality of the work done by them. This work, however, was heavily handicapped. The writers had to rely upon the data of the early amateur ethnographers-modern field-work of the trained specialist, done with method, purpose and knowledge of the problems, was at that time not yet in existence. In an abstract and complex subject, such as primitive law, amateur observations are, on the whole, useless.

The early German students of savage law again were all and one committed to the hypotheses of "primitive 